\title{
ДЕКАНОНИЗАЦИЯ ЖАНРА ТОРЖЕСТВЕННОЙ ОДЫ В ТВОРЧЕСТВЕ М. МУРАВЬЕВА
}

\section{В статье рассматривается проблема деканонизации жанра торжественной оды в «легкой поэзии» М. Мура-} вьева. Одическое творчество поэта классифицируется согласно тематике и подвергается риторико-дискурсивному анализу в аспекте коммуникативно-прагматической направленности, риторической топики.

К кониу ХVIII столетия потребность приобщения лирической поэзии к жизни государства стремительно утрачивает необходимость. Поэт становится выразителем и комментатором собственных чувств, жизненных перипетий, внутренних конфликтов. При этом зачастую авторы используют прежние жанры, внося в них творческие коррективы: изменяя форму, жанровые стратегии, посягая на композицию.

Подобные превращения происходят и с одами М. Муравьева, который решительно экспериментирует со строфической формой, одической диспозицией, риторическими топосами. Одь нумерованного ичикла отличаются от ранних батальных од М. Муравьева свободным обращением с канонической жанровой формой. Так, в философских одах автор, прибегая к наставлениям, окрашенным драматическим пафосом, подчеркивает собственную разносторонность и затрагивает вопросы о бренности человеческого существования: суетности, самоуверенности, тщеславии и безбожии.

Эстетические взгляды М. Муравьева формировались в условиях выбора между военной карьерой и литературным творчеством, что оставило свой неизгладимый след в его поэзии. Автор собственноручно отрекается от высокой лирики, отдавая предпочтение теме природы. Тема войны раскрывается в одическом творчестве М. Муравьева многогранно: и в виде поучения желающих нести военную службу, и как послание антивоенного характера.

Анализ «легких од» поэта подчеркнуто демонстрирует жанровую модификацию торжественной одь, что подтверждается нарушением ряда жанровых признаков (формальных, композиционных и прагматических) $u$ отказом от использования риторических топосов и традиционных мотивов.

Ключевые слова: торжественная ода, деканонизаџия, жанровая стратегия, диспозиция хрии.

\author{
Наталія ВОЛІК, \\ orcid.org/0000-0002-7175-944X \\ кандидат філологічних наук, \\ дочент кафедри слов 'янської філологї та перекладу \\ Маріупольського державного університету \\ (Маріуполь, Донецьька область, Україна) 1978natty@gmail.com
}

\section{ДЕКАНОНІЗАЦІЯ ЖАНРУ УРОЧИСТОЇ ОДИ У ТВОРЧОСТІ М. МУРАВЙОВА}

Стаття присвячена проблемі деканонізачії жанру урочистої оди в «легкій поезї̈» М. Муравйова. Творчість поета в одичному жанрі підлягає риторико-дискурсивному аналізу в аспекті комунікативно-прагматичної спрямованості та риторичної топіки, а також класифікується відповідно до тематики.

Наприкінці XVIII століття залучення ліричної поезії до потреб державної сфери управління стрімко втрачає свою необхідність. Поет починає виступати виразником і коментатором власних почуттів, життєвих перипетій, внутрішніх конфліктів. Частіше за все автори використовують попередні жанри, втілюючи в них власні творчі корективи: змінюючи форму, жанрові стратегії, навіть зазіхаючи на композицію.

Саме такі перевтілення відбуваються з одами М. Муравйова, який рішучо експериментує зі строфічною формою, одичною диспозицією, риторичними топосами. Оди нумерованого ииклу вирізняються досить вільним поводженням із канонічною жанровою формою, щяо протиставляється раннім батальним одам М. Муравйова. Саме у філософських одах поет вдається до наставляння, сповненого драматичним пафосом, підкреслює власну різнобічність і торкається питань щчодо тлінності людського існування: суєтності, самовпевненості, марнославства та безбожництва.

Естетичні погляди М. Муравйова формувалися в умовах вибору між військовою службою та літературною творчістю, щуо залишило свій відбиток у його поезії. Автор власноруч відмовляється від високої лірики та надає 
перевагу темі природи. Тема війни розкривається в одичній творчості М. Муравйова досить багатогранно: і як повчання бажаючим нести військову службу, і як послання антивійськового характеру.

Аналіз «легких од» поета підкреслено демонструє жанрову модифікацію урочистої оди, щуо знаходить підтвердження у порушенні низки жанрових ознак (формальних, композиційних, прагматичних) $i$ відмові від використання риторичних топосів і традиційних мотивів.

Ключові слова: урочиста ода, деканонізація, жанрова стратегія, диспозиція хрії.

Nataliia VOLIK,
orcid.org/0000-0002-7175-944X
Candidate of Philological Sciences,
Associate Professor at the Department of Slavonic Philology and Translation
Mariupol State University
(Mariupol, Donetsk region, Ukraine) 1978natty@gmail.com

\section{DECANONIZATION OF THE SOLEMN ODE GENRE IN THE CREATIVITY OF M. MURAVYOV}

The article deals with the problem of decanonization of the solemn ode genre in "light poetry" by M. Muravyov. According to the subject odic creativity of the poet is classified as philosophical, military and art's poetry.

Poetic works are subjected to rhetorical and discursive analysis in the aspect of communicative and pragmatic orientation, rhetorical topics. By the end of the $18^{\text {th }}$ century lyrical poetry rapidly ceases to interfere in the state's life. The poet becomes an exponent and commentator of his own feelings: as life's vicissitudes and internal conflicts. At the same time authors often use previous genres. They make creative adjustments: changing the form, genre strategies, encroaching on the composition.

M. Muravyov's odes occur the similar transformations. He strongly experiments with strophic form, odic disposition and rhetorical toposes. The odes of the numbered cycle characterize by free handling of the canonical genre form. They differ from the early battle M. Muravyov's odes. In philosophical odes the author appeals to instructions and dramatic pathos. There are many questions about the impermanence of human existence poet concerns. For instance, he names worldliness, self-confidence, vanity and godlessness.

Aesthetic views of M. Muravyov were formed in the conditions of choosing between a military career and literary work. This fact left an indelible mark in his poetry. The author personally renounces high lyrics and prefers the theme of nature. The theme of war is ambiguously revealed in the odic work of M. Muravyov. At one side it is an instruction for people who want to serve in the military. At other side, he becomes an anti-war message.

The analysis of the poet's "light odes" emphatically demonstrates the genre modification of the solemn ode. It is confirmed by the violation of a number of genre features (formal, compositional and pragmatic) and the refusal to use rhetorical toposes and traditional motifs.

Key words: solemn ode, decanonization, strategy of genre, hria's disposition.

Постановка проблемы. Исторически сложившиеся особенности литературного процесса XVIII столетия во многом определили функционирование художественной литературы в гражданских и политических целях, о чем свидетельствовала ораторская направленность жанров оды, сатиры, элегии.

Особой печатью риторики в русской литературе этого периода был отмечен жанр оды. Композиционная близость жанра оды к ораторской проповеди и ее публичная ориентация, закрепленные в риторических пособиях, сформировали признаки жанрового канона торжественной оды, которые к концу столетия утрачивают свою актуальность и трансформируются в другие жанровые формы. Следствием этого становится непрестанное внимание исследователей к вопросу о жанровых разновидностях, дискурсивной направленности, модификации или трансформации одического канона, разрушении жанра
(Г. Гуковский, Ю. Тынянов, И. Серман, Н. Алексеева, Г. Москвичева, Е. Погосян, Т. Абрамзон, Л. Копаница и другие).

На протяжении своего существования русская ода, по мнению Н. Алексеевой, проходит три этапа развития: горацианская ода (школьная поэзия) до 30-х годов XVIII столетия, позднее классицистическая (пиндарическая, торжественная (комплиментарная)), в конце века в творчестве Г. Державина анакреонтическая ода (Алексеева, 2005). Однако именно торжественная ода становится ведущим государственным жанром, поскольку поводом для ее написания являются события общегосударственного значения (коронация, день рождения, бракосочетание, смерть монархов, военные победы). В тени этой одической жанровой разновидности все столетие остаются оды духовного, пейзажного, любовного содержания, которые незаслуженно воспринимаются как вторичное явление. 
Анализ исследований. Немногочисленное стихотворное творчество М. Муравьева, датированное преимущественно концом 70-х - началом 80-х годов, содержит в себе как образцы жанра торжественной оды, так и примеры «легкой поэзии», которые и представляют интерес в аспекте изучения жанровой деканонизации.

Поэтическое наследство автора неоднократно становилось предметом исследования А. Пашкурова, Л. Кулакова, В. Топорова, А. Кистанова, И. Никитина, С. Скибина и других. Так, А. Кистанова отмечала «жанровую размытость» еще в батальных и торжественных одах поэта, констатируя присутствие «новых черт, которые реализуются на различных уровнях поэтического текста» (Кистанова, 2015: 140). С. Скибину заинтересовала жанровая горацианская рецепция в поэзии М. Муравьева. И. Никитина подчеркивает новаторский характер его поэзии, которая является новой ступенью на пути становления предромантизма. Наше внимание привлекает риторико-дискурсивный анализ жанрового канона так называемых «легких од» М. Муравьева в аспекте их коммуникативной направленности.

Цель исследования - проанализировать модификации одического жанрового канона в аспекте риторического дискурса (его коммуникативнопрагматической стратегии), а также риторической топикинаматериале«легкойпоэзии»М.Муравьева, собственноручно названной автором жанром оды.

Изложение основного материала. Среди поэтических произведений этого жанра мы остановимся на небатальных одах М. Муравьева, вошедших и не вошедших в так называемый нумерованный цикл. По своим жанровым характеристикам они противопоставляются одам на случай, написанным ранее («Ода на случай Кагульския битвы», «Ода на примерное взятие городка на Выборгской стороне в 1773 году», «Ода на победы, одержанные российским оружием в продолжение первой турецкой войны» и другие). Избранные оды гармонично классифицируются по группам в зависимости от преобладающей тематики:

1) война («Ода седьмая», «Тревожится кипяща младость...»);

2) искусство («Ода четвертая», «Ода шестая [К Д***]», «Ода десятая», «Священный замысл порывает...», «Восприял я лиру в длани...»);

3) философские размышления («Ода вторая», «Ода третия», «Ода шестая», «Ода девятая», «Бежит, друзья, бежит невозвратимо время...»).

Как отмечалось в наших предыдущих исследованиях, дискурсивная модель жанра торжественной оды, обличенная в поэтическую форму с многочис- ленными лирическими отступлениями, зачастую формально повторяла строение ораторских речей (панегирика, хрии). Композиционное исследование нумерованных од М. Муравьева позволяет нам сделать вывод о том, что формальные нарушения жанрового канона сочетаются в них с художественной диспозицией (расположением) неполной хрии. Согласно риторическому руководству М. Ломоносова 1744 года «хрия состоит из восьми частей: 1) приступ, 2) парафразис, 3) причина, 4) противное, 5) подобие, 6) пример, 7) свидетельство, 8) заключение» (Ломоносов, 1952: 296).

Жанровый канон оды, созданный трудами В. Тредиаковского, М. Ломоносова, А. Сумарокова и других, предполагал соответственную форму: строфу из десяти стихов, ямбический стихотворный размер, определенный способ рифмовки. Анализ небатальных од М. Муравьева демонстрирует формальное нарушение сложившейся одической традиции: из двенадцати текстов четыре написаны пятистопным хореем, а восемь - ямбом. При этом прослеживается изменение строфической политики (использование шестистишных и четырехстишных строф). Однако нарушения внешнего жанрового устройства оды не являются основными признаками ее деканонизации. В «легких одах» М. Муравьева фактически нивелируется главная прагматическая функция торжественной оды - громогласно и возвышенно сообщать о важных для всего государства явлениях.

Обязательный для жанра торжественной оды адресат присутствует только в семи одах, при этом поводом к их написанию было происшествие отнюдь не государственного значения. Например, «Ода вторая. К А.М. Брянчанинову» (1775) была приурочена поэтом к началу военной карьеры, что повлекло за собой отказ от занятий творчеством. Она посвящена родственнику, вологодскому помещику. От одического канона в тексте остаются мифологические мотивы, представленные образами бога войны («Богу браней посвятился // Неминуемой судьбой») и парнасских муз (Муравьев, 1967: 117). Интересно, что этикетный топос неподражаемых муз, которые являлись источником поэтического вдохновения, теперь декларируется как факт прошлой жизни («Музы! вы меня прельщали, // Но в то время не смущали // Бранны громы суетой») или даже как нечто враждебное («А пермесские богини // Стали днесь мои врагини») (Муравьев, 1967: 117-118).

Прагматика оды, несмотря на ее коммуникативную направленность, выраженную посредством диалогического общения автора с адресатом, заключается в аргументации для читателя брен- 
ности человеческого существования и внезапности смерти («Мой любезный брат скончался // На брегах, где ополчался <..> Мы судьбы своей не знаем: // Гром метая за Дунаем, // Он пал, громом поражен») (Муравьев, 1967: 118). Высокий стиль изложения оды не определяет соблюдение композиционных и функциональных жанровых стратегий: восхвалять, превозносить, наставлять и убеждать, то есть содержательно она носит характер философских размышлений.

«Ода третия» (1775 год) всецело посвящена порицанию суеты как главного человеческого порока («Суета есть идол мира, // Выше нет сего кумира, // Им живут, им дышат все»). Она является поэтическим примером обвинительной речи, написанной в соответствии с композицией хрии (Муравьев, 1967: 119). Тему философской оды автор предлагает читателю в приступе: «Смертный суетен родился // И навеки осудился // Суетой себя прельщать» (Муравьев, 1967: 119). Ниже наводятся доказательства в пользу выдвинутого тезиса:

1. «Суета есть идол мира, // Выше нет сего кумира».

2. «В суете нам нет упреки: // Чем бы стали человеки // Утешаться в тесноте?»

3. «Земнородных обладатель, // Не судья лишь оправдатель // Беззаконий наших ум».

4. «Льзя ль с рассудком воевати? // И возможно ль отмщевати, // Если ум наш говорит?» (Муравьев, 1967: 119).

В тексте оды присутствует и противовес, представленный противоположной стороной человеческой жизни и несчастьями, которые приносит человеку его же идол: «Скорбный век препровождая, // В самом счастии страдая, // Горьку желчь всегда пием» (Муравьев, 1967: 119). Таким образом размышления об одном из пороков человечества сочетается с отсутствием мотивов, свойственных для жанра оды, и логически выстроенной диспозицией ораторской речи, целями которой является воздействие на слушателей и их убеждение.

«Ода шестая» (1775 год) отличается дискурсивной направленностью, поскольку адресована непосредственно человеку, чья бренная жизнь ему абсолютно не подвластна. Однако в тексте оды не просматривается ни риторических топосов, ни четкой одической композиции: она состоит из двух частей - рассуждения о бренности, недолговечности нашей жизни и обращения к обобщенному образу человека. Автор последовательно от констатации своих убеждений («Едва родимся мы, уж стонем // И прежде в бедствиях потонем, // Чем будем помнить мы себя») переходит к наставлениям («Уничижи свою кичливость, // Прерви ленивую сонливость // И внидь в себя, о человек!») (Муравьев, 1967: 121-122). Переход от неопределенно-личного повествования в духе философского рассуждения к определенно-личному монологу подчеркивает драматизм человеческой жизни и желание поэта максимально воздействовать на легкомысленного читателя.

Согласно плану ораторской речи написана «Ода девятая» (1775 год), адресованная Богу, к которому герой обращается с отчаянным призывом уже в приступе: «Умедли гневом совершенным // Сразити бедну жизнь мою» (Муравьев, 1967: 124). Парафразисом к этой теме являются оправдания лирического героя: «Я согрешил, но зри: я каюсь, // Я признаю, что претыкаюсь, // И плачу, будучи столь слаб; // Во всем перед тобой виновен, // Во всем перед тобой бессловен // Тебе молящийся твой раб» (Муравьев, 1967: 124). Вторая и третья одические строфы содержат причины этого обращения к богу: «Но, боже! я средь заблужденья // Чуждался истины твоей», «Наполнясь сердце срамотою, // Прельстилось мира суетою», «Мои покрылись очи тьмой», «Мое я знаю преступленье» (Муравьев, 1967: 124).

Противовесом словам кающегося героя с мольбами о спасении становится приговор (четвертая строфа): «Ах! лучше, лучше бы стократно // Мое пресеклось бытие <...> Меня творец мой осуждает, // И кто пред ним мя оправдает? // Погиб, погиб уж я навек» (Муравьев, 1967: 124-125). В пятой строфе наряду с подобными самоуничижительными призывами («Рази, великий бог, в меня», «Я раб, ты - мира обладатель») лирический герой в последних строках высказывает сомнение, опровергающее логику всего текста: «Но славно ль то твоей деснице - // Разить толь малу тварь, как я?» (Муравьев, 1967: 125).

По-разному раскрывается в одическом творчестве М. Муравьева тема войны: и в виде наставления желающим военной службы, и как антибатальное послание пацифистского характера. «Ода седьмая» (1775 год) написана в форме поучительного обращения к тем, кто мечтает о военной карьере, что заявлено в теме: «Но прежде чем в сраженьях мчиться, // Довлеет, други! Научиться // Собой самим повелевать» (Муравьев, 1967: 123). Вторая строфа оды представляет собой перефразис, расшифровывающий содержание предыдущей строки. Перед адресатом выстраивается целая программа по самосовершенствованию: 1. «Вождям своим повиноваться». 2. «Уметь сносить и не роптать». 3. «С свободной жизнью расставаться». 4. «А срамный шаг исполнь позора». 5. «Не дрогни вражеского взора» (Муравьев, 1967: 123). 
Причина к действию звучит уже в третьей строфе: «Когда ты все дела сочтешь // Явится более иройства, // Как сколько в повестях прочтешь» (Муравьев, 1967: 123). Последняя строфа содержит противное теме: «Тщетна вся храбрость без науки // И без величия души: // Исправи ум, настави руки // И лишню буйность потуши». Пример исторического характера, подразумевающий, что военная стратегия не терпит суеты и самонадеянности: «Не ограждаясь боле валом, // Минуций шел за Аннибалом // Во неминуему напасть» (Муравьев, 1967: 123). Дискурсивная направленность оды, изменив «одеяние», соблюдает задачу воспитать мудрых, дисциплинированных, грамотных и смелых воинов.

Ода «Тревожится кипяща младость...» (1776 год) композиционно не подчиняется законам хрии и строится по принципу антитезы: первые три строфы отображают картины мирной жизни, а две последние передают состояние войны и ее неприятие лирическим героем. Идиллические ощущения создаются в начале стихотворения посредством изображения тихих весенних пейзажей и ряда мифологических образов. Так, главными поэтическими символами покоя являются образы Аполлона, который в мирное время призывает творить, и Зефира, теплого южного ветра: «Весна вливает в чувства сладость, // И увлекает Аполлон», «Бряцайте, струны, // Вас внемлют тихи небеса, // Зефир, крутись, молчат перуны» (Муравьев, 1967: 151). Не менее убедительным выглядит бог войны Арес, сладко спящий в тишине: «Обезоружен спит бог брани, // Окованы раздора длани, // И мир подруг его прогнал〉 (Муравьев, 1967: 151).

Поэт как лирический повествователь одновременно является полноправным участником этой ситуации, что следует из употребления им повелительных конструкций во втором лице единственного числа: «Постой: пусть он еще просвищет», «Бряцайте, струны», «Зефир, крутись». Картину мирной тишины сменяет с приходом темноты образ «любимицы хаоса смрадной» - богини Раздора и жестокий смертельный бой отца с сыном. Эмоционально звучит обращение автора к войне: «Умчись, умчись, война ужасна!» и предпочтение ей тишины и мира без героев: «Когда не ведали булата, // Тогда златой был в мире век» (Муравьев, 1967: 152). Дискурсивная прагматика оды апеллирует не к разумной логике, а к чувствам читателей, хотя поэт неоднократно прибегает к историческим деталям (окончание русско-турецкой войны, подавление крестьянских восстаний).
Как неполная хрия «Ода четвертая» (1775 год) отвечает одной из своих главных жанровых целей - прославлению поэзии. Тема оды: «Стихотворство сотворило // И богов и чудеса» (Муравьев, 1967: 120). Доводами к выдвинутому тезису являются многочисленные примеры из мифологии: Геракл, укрощенный лирой Лина («Обуявши, подвизался // На природу исполин, // Но согласьем он стязался // Струн твоих, священный Лин»); чудесные музыкальные способности Орфея, которые оказались беспомощными перед силами царства теней («Древни дубы изумлялись // И за лирой устремлялись, // В кою ты бряцал, Орфей»); лира Амфиона, управляющая камнями («Камни звуком извождались // И в чертоги созидались, // Как содейством неких уз») (Муравьев, 1967: 120-121). Однако привычное для одического жанра заключение в этом тексте отсутствует. Вместо него поэт приводит популярный риторический топос «несовершенство авторских произведений»: «Можно ль в слабу песнь включити // Все благодеянья муз?» (Муравьев, 1967: 121).

«Ода десятая. Весна» (1775 год) адресованная наставнику поэта Майкову, она служит примером стихотворной симфонии весенней природе. М. Муравьев приводит традиционный для торжественной оды npucmyn: «Весну хочу гласить я ныне // И Филомелиных подруг» (Муравьев, 1967: 125). Однако затем прославление весны превращается в многогранное описание весеннего пробуждения природы, затянувшееся на девять десятистиший. Стихотворение перенасыщено культурными мифологическими кодами, отсылающими читателя к ряду древних легенд, связанных с образами греческой и римской мифологии: Зефир, Борей, Ирида, Аврора, Нептун. Адресат оды появляется в тексте лишь в последней строфе как главный учитель и вдохновитель лирического героя, наставления которого были отвергнуты им по причине излишней чувствительности: «Я прежде пел сраженья звучны, // А днесь гласил растенья тучны, // В полях биющие ключи; // Ты брани петь меня наставил, // А я тебе сей стих составил // Во знак чувствительной души» (Муравьев, 1967: 127-128).

Подобно лирической исповеди героя о поэтическом искусстве предстает «Ода шестая [К Д***]» (1775 год), в которой автор представляет свою эстетическую программу, обозначая собственные ценностные ориентиры в мире поэзии. Этот пример далек от одического канона, поскольку по форме и композиции является образным высокопарным рассуждением о воздействии поэзии на воображение: «Лишь струны вдруг ее златые 
забряцают - // Яснеют небеса, // И воздух сладостны дыханья проницают, // И смолкнут древеса» (Муравьев, 1967: 155).

Неизменно обращаясь к древнегреческой культуре, М. Муравьев избирает несколько фигур, сыскавших, по его мнению, поэтическую славу: Алкей, Пиндар и Гораций. Видимо, образ Алкеявоина был близок поэту, делившему свое вдохновение с бранной службой: «Лесбийский гражданин ходил в потоках крови // И волны преплывал, // Однако ж чистых муз и с Вакхом мать любови // Муж бранный воспевал» (Муравьев, 1967: 155). Величественный Пиндар просто недосягаем, а о себе герой самокритично пишет: «Я - слабый ученик любовника Глицеры, // С трудом сбираю сот // И, в мягких утаясь убежищах пещеры, // Склоняюсь от высот», тем самым обосновывая отнюдь не одические принципы (Муравьев, 1967: 155).

Не раз лирический герой М. Муравьева обращается к своему поэтическому наставнику Майкову, прямо или опосредованно представляя его в качестве адресата: «Вот, Майков, плод твоих советов! // Жалей питомца своего, // Преступник он своих обетов // И наставленья твоего» (Муравьев, 1967: 150). «Ода. Священный замысл порывает...» (1776 год) в высоком стиле отображает внутренний конфликт и проблему выбора, которые бесконечно терзают героя: это и желание «греметь», и обязанность «Так должно лиру мне расстроить!..» (Муравьев, 1967: 150). Драматизм повествования достигается при помощи анализа собственных чувств и эмоций («Жесток, жесток я безвозвратно, // Коль растерзаю, что приятно, //
Что мило сердцу моему»), а также обращений к Майкову («Услышь: коль ты меня не любишь, // Так знай, что тем меня ты губишь // И ненавижу я себя») (Муравьев, 1967: 150).

Своеобразным творческим завещанием может считаться «Ода. Восприял я лиру в длани» (1775 год) с утверждением об отказе от высокой одической поэзии. В ней герой отрекается от дискурсивной прагматики своих текстов и их коммуникативной направленности: «Я, покинув звуки громки, // Не для вас пою, потомки» (Муравьев, 1967: 122).

Выводы. Примеры жанра оды в «легкой поэзии» М. Муравьева достаточно отчетливо демонстрируют разноаспектную деканонизацию жанра торжественной оды. Это явственно следует из расхождения формальных, композиционных и прагматических признаков одических текстов. Поэт соблюдает высокий стиль изложения, последовательно отказываясь от использования общих риторических мест и традиционных мотивов в философской лирике.

Коммуникативная направленность од М. Муравьева ослабевает, а функция адресата зачастую становится номинальной. При этом диспозиция неполной хрии, сохранившаяся в отдельных одах, сочетается с нивелированием ее хвалебной и наставительной прагматики. Поэтому утверждать, что М. Муравьев решительно игнорирует жанровый канон, не представляется возможным. Уместнее было бы отметить творческое использование поэтом одических инструментов для создания своей лирической поэзии.

\section{СПИСОК ИСПОЛЬЗОВАННЫХ ИСТОЧНИКОВ}

1. Алексеева Н. Ю. Русская ода: Развитие одической формы в XVII - XVIII веках. М. : Наука, 2005. 371 с.

2. Кистанова А. В. Жанр оды в теоретической рефлексии английских поэтов XVII - XVIII веков (А. Каули, У. Конгрив, Э. Юнг). LIBRIMAGISTRI: Вып. 1. Магнитогорск : ИЦ МГТУ, 2015. С. 9-17.

3. Ломоносов М. В. Полное собрание сочинений: в 10 т. М.; Л. : Изд-во АН СССР, 1950-1983. Т. 7: Труды по филологии 1739-1758 гг., 1952. 997 с.

4. Муравьев М. Н. Стихотворения. Л. : Изд-во «Советский писатель», 1967. 388 с.

\section{REFERENCES}

1. Alekseeva N. IU. Russkaia oda. Razvitie odicheskoi formy v XVII - XVIII vekakh [Russian ode. Development of the Odic form in the $17^{\text {th }}-18^{\text {th }}$ centuries]. M. : Nauka, 2005. 371 p. [in Russian].

2. Kistanova A. V. Zhanr ody v teoreticheskoi refleksii angliiskikh poetov XVII - XVIII vekov (A. Kauli, U. Kongriv, E. Iung). [Ode genre in theoretical reflection of English poets of the $17^{\text {th }}-18^{\text {th }}$ centuries (A. Cowley, W. Congreve, E. Jung)]. LIBRIMAGISTRI: vyp. 1. Magnitogorsk : IC MGTU, 2015. P. 9-17 [in Russian].

3. Lomonosov M. V. Polnoe sobranie sochinenii v 10 tomakh [Complete works in 10 volumes]. M., L. : Izd-vo AN SSSR, 1950-1983. T. 7: Trudy po filologii 1739-1758 gg., 1952. 997 p. [in Russian].

4. Muravev M. N. Stikhotvoreniia [Poems]. L. : Sovetskii pisatel, 1967. 388 p. [in Russian]. 